Loetscher, K. M. (1962). Rep. Fishg Ind. Res. Inst., Cape Tn 16, 70

Power, H. E. (1962), F. Fish. Res. Bd Can. Ig, 220.

Snyder, D. G. (1967). Process Development by the Bureau of Commercial Fisheries. Paper at Conference on FPC, Ottawa, October $24 \& 25$.

Thomson, F. A. \& Merry, E. (1962). Br. Y. Nutr. 16, 175.

U.S. Bureau of Commercial Fisheries (1966). Fishery Leafl. Fish Wildl. Serv. U.S. $5^{84}$.

\title{
The production and use of leaf protein
}

\section{By N. W. PIRIE, Rothamsted Experimental Station, Harpenden, Herts}

The proposal that a new foodstuff should be made and used encounters different forms of scepticism from different groups of people. But every proposal will meet scepticism in some form. Although irrational scepticism, or 'instant opposition', may in practice be the most troublesome, it may be disregarded in the context of this meeting and the remaining forms may be arranged as a quasi-logical sequence of questions: Is a novel food needed? Would the one proposed contribute significantly to meeting the need? How would it be made? What would it be made from? How would it be used? What is its relationship to other comparable proposals?

The first question is answered by the fact that we are holding this meeting and by Woodham's paper, the second can be subdivided into three parts: Would the product be available in places where it is actually needed? Would it be feasible to make enough of it to be of practical importance? What evidence is there about its nutritional value?

Most of the people who are now in greatest need of extra protein live in the wet tropics. Furthermore, they do not live in urban areas, or even in the shanty-towns that are insidiously growing around them, but in country districts with poor communications. One very important practical need is therefore for a method of producing protein from a local source. The quickest and most practical way to increase the use of leaf protein in these regions is to encourage the use of leafy vegetables. Nevertheless, although most communities could with advantage eat more vegetables, an upper limit is set by human physiology. This limit can be circumvented by separating protein from fibre mechanically. Quantitatively, this method of making protein would be unrivalled in tropical regions with regular heavy rainfall. Even in Britain we can get $\mathrm{I}^{*} 4$ tons of extracted protein from a hectare in a year; this is as good as the protein yields claimed for soya or groundnuts in climates adapted to them, and we expect to reach 2 tons. In Mysore, 3 tons per hectare has already been reached. There has as yet been little agronomic work on leaf protein production and no work at all on breeding plant strains suited to this purpose.

The amino acid compositions of protein samples from leaves of different species, ages and cultural background are similar (e.g. Pleshkov \& Fowden, I959; Chibnall, Rees \& Lugg, 1963; Gerloff, Lima \& Stahmann, 1965). I am unconvinced that any of the apparent differences are greater than the possible error in the determinations. This is not unexpected because what is loosely called leaf protein is a mixture 
of many individual proteins and it is unlikely that the same amino acid would be abundant or scarce in all of them. In this respect the leaf resembles a metabolically active animal organ such as the liver rather than simpler structures or organs such as bones or seeds. Methionine is the amino acid that varies most; some excessively small values have been reported. But it is seldom clear that proper allowance was made for sulphoxide formation throughout the analysis, and for the effects of other components of the leaf protein preparation on the extent to which sulphoxide is formed. The values in Table I are probably representative and suggest that leaf protein should be a better supplement to a protein-deficient diet than most of the seed proteins, and should be as good as the animal proteins, apart from those in egg and milk, which are the end-product of several million years of adaptation to the feeding of young animals. This expectation is borne out experimentally. Duckworth, Hepburn \& Woodham (196I) found it as effective a supplement in the diet of growing pigs as fish meal, Waterlow (1962) found that nitrogen retention was nearly as good during the re-feeding of malnourished infants with equal parts of milk and leaf protein as with milk alone, and Doraiswamy, Singh \& Daniel (I969) found that 6-I2-year-old children grew better on a diet supplemented with leaf protein than on one supplemented with sesame protein.

Table $\mathrm{I}$. The range within which trustworthy amino acid analyses come on twenty bulk preparations of leaf protein from twelve species. The results are expressed as $g$ amino acid/100 $\mathrm{g}$ amino acid accounted for in the analyses. No results are included in which the recovery was less than $90 \%$

$\begin{array}{lcc}\quad \text { Amino acid } & \text { Range } & \begin{array}{c}\text { FAO (1965) provisional } \\ \text { recommendation }\end{array} \\ \text { Isoleucine } & 4 \cdot 7-5 \cdot 2 & 4 \cdot 2 \\ \text { Leucine } & 8 \cdot 8-10 \cdot 0 & 4 \cdot 8 \\ \text { Lysine } & 5 \cdot 6-7 \cdot 1 & 4 \cdot 2 \\ \text { Methionine } & 1 \cdot 7-2 \cdot 8 & 2 \cdot 2 \\ \text { Phenylalanine } & 5 \cdot 5-6 \cdot 4 & 2 \cdot 8 \\ \text { Threonine } & 4 \cdot 8-5 \cdot 7 & 2 \cdot 8 \\ \text { Tryptophan } & 1 \cdot 7-2 \cdot 3 & 1 \cdot 4 \\ \text { Tyrosine } & 3 \cdot 9-4 \cdot 6 & 2 \cdot 8 \\ \text { Valine } & 6 \cdot 0-7 \cdot 2 & 4 \cdot 2 \\ \text { Cystine values uncertain: about } 1 & \end{array}$

In spite of their uniformity in amino acid composition, leaf protein preparations are not all equally good as protein supplements (Henry \& Ford, 1965; Woodham, 1965). Studies on enzymic hydrolysis (Byers, 1967a,b; Buchanan, 1969a) had made us suspect that this variation resulted from different degrees of complex formation with other components in the preparations. This suspicion was amply confirmed by Buchanan (1969b). Most of the preparations used contained $20-30 \%$ of lipid and it has been known for many years that leaf lipids are highly unsaturated. Lima, Richardson \& Stahmann (1965) found interesting differences in the proportions of different unsaturated fatty acids in protein preparations from different species, and Buchanan $(1969 a, b)$ studied the conditions in which indigestible complexes were formed and resolved. On present evidence there seems no reason to look beyond 
uncontrolled complex formation for an explanation of the observed differences in nutritional value. As with other food proteins (c.f. Woodham, ig64), those preparations that give the best results establish the potentialities of the source: the problem is to define conditions in which this good quality can be maintained systematically.

It seems therefore that leaf protein would be nutritionally valuable and could be made on a very large scale at many centres in many of the regions where there is most need for new protein sources. The last point deserves constant emphasis. According to a United Nations (I 668 ) report, of the 6 million tons (dry matter) of skim milk that are available, only $\mathbf{I} \cdot 2$ million tons are eaten by people. The report adds: 'It is more profitable to use this product for the production of meat in western Europe than to sell it to the more needy groups of the human population.' The essence of our problem is to devise methods for making proteins that will reach the people who need them.

All the samples of leaf protein used in our recent feeding experiments were made by methods that differ in no more than scale and detail from those used in the laboratory for $\mathrm{I} 95$ years. We pulp the crop at its own $\mathrm{pH}$ (usually $5 \cdot 8 \cdot 6 \cdot 3$ ) and add only enough water during pulping to increase the water content of the pulp to $90-92 \%$ (Morrison \& Pirie, $196 \mathrm{I}$ ). It is well known that more protein can be extracted if the $\mathrm{pH}$ or water content is increased but, with most species of leaf, we doubt the practical value of doing these things - especially when the fibre, containing the unextracted protein, is to be used as a fodder. In the laboratory, protein is usually precipitated by adding salt or acid to the juice pressed out of the pulp; in large-scale work it is more convenient to use heat $\left(>70^{\circ}\right)$ because the curd is then easier to filter off. We then wash the curd at about $\mathrm{pH}_{4}$ to remove flavour and alkaloids, should any be present in leaves used, and also to promote easy filtration and to yield a product that has, in the moist state, the keeping qualities of cheese or sauerkraut. The press-cake is dark green and contains $40 \%$ of dry matter; the dry matter is $60-70 \%$ protein. When possible, it is used in this form. But it can be dried, provided it is not overheated (Duckworth \& Woodham, I961), canned, or preserved by pickling (Subba Rao, Singh \& Prasannappa, 1967). We hope that it will not prove necessary to remove the lipids by solvent extraction because this extra process would increase the cost and would probably make the process unworkable by the technically unsophisticated people to whom leaf protein would be of most use. Even in Britain, farmers who use combine harvesters and milking machines with assurance might hesitate before embarking on routine solvent extraction. Similarly, attractive as the idea of enzymic or fermentative liberation may be, any such process would probably demand too much skill.

Ideally, leaf protein would be made from leaves that are the by-product of some other crop. In the temperate zone the obvious sources are pea and bean haulms from canneries, and the tops from early potatoes and sugar-beet. Because the protein is washed, both neutral and acid, leaves that are toxic in the raw state, can be used. In the tropics there are potentialities in jute, ramie and sweet potato. In some regions cotton, groundnut and sugar-cane might be used. The last is interesting because of its abundance; but sugar-cane tops contain little protein 
and are very tough. It is unlikely that continuous production could be maintained, even in the tropics, on by-products. There is no objection to the leaves of some trees provided a method of collection can be devised. Leaves that fall naturally from deciduous trees contain little protein. Production might be maintained on water weeds such as papyrus, Pistia, Salvinia, and water hyacinth; but research on these potential sources, and on a barge-mounted extraction unit, is needed.

Weeds growing on land are not a probable source. Production on a reasonable scale depends on some form of mechanical harvesting; that means the use of arable land. If arable land is being used, it might as well grow the crop, though this may well be something now classified as a weed, that is best adapted to local conditions. In any region, crops grown specially for the purpose are likely to be the main source of protein, and the justification for diverting to this use land that is, or could be, used for growing a conventional crop is that the yield of protein per hectare and year would thereby be enhanced. This increased yield is most likely in the wet tropics where many seed crops do not flourish, but it has still to be demonstrated experimentally.

The agronomic study of leaf protein production is one facet of the work of the International Biological Programme (IBP) and is now being undertaken in Britain, India, New Zealand, Nigeria and Sweden. We have assumed that the equipment used on a large scale will resemble to some extent the pulpers (Davys \& Pirie, I960; Pirie, I968) and press (Davys \& Pirie, 1965) that we now use. With support from the IBP, we have therefore made a pulper and press (Davys \& Pirie, I969; Davys, Pirie \& Street, I 969 ) that simulate the action of large-scale equipment but require only 2-3 $\mathrm{kg}$ (fresh weight) of leaf, i.e. the amount that would be harvested from a few square meters of ground. During the next few years we hope measurements will be made of the yield of extractable protein from many different crops, growing in different climates, and harvested at different ages after different fertilizer treatments. It is already known that the percentage of extractable protein in a leaf tends to diminish as the crop matures although the total amount of protein per hectare is still increasing. This results in an optimum harvest date; the age of the leaf at this optimum depends on species and cultural conditions. Clearly, once the idea of using leaf protein has been accepted in any region, there will be no lack of research problems for agronomists and plant physiologists. As a result of cooperative IBP studies, present ideas of a good protein yield are likely to seem unduly modest.

No novel food, regardless of its intrinsic merits, is likely to be accepted immediately by most adults. There is however widespread and entirely unwarranted pessimism about the prospects of changing food habits. A set of probably apocryphal stories gets bandied about and the usual attitude of officials from industrialized countries is that the foods that they use are the only novelties that are likely to be accepted in developing countries. There is ample evidence that, with skill and patience, acceptance can be won for a novelty within a few weeks or months. To get that evidence the middle aged need only recall the contents of shops in their youth. For further evidence one can look at figures for the consumption of such 
products as Incaparina or soft drinks - even the new and nutritionally valuable ones based on soya and groundnut protein. There are two modes of approach to the problem: a novelty should either be introduced first in a region where its form is compatible with the existing cuisine, or it should be introduced under the auspices of local people who will give it a certain prestige. The way to ensure failure is to introduce it before elaborate private cooking experiments are completed, or to introduce it first as food for criminals, orphans or other unfortunates. I have discussed these issues at greater length elsewhere (Pirie, ig68).

Leaf protein in its dark-green form is acceptable in West Africa (Akinrele, 1963 ; Oke, I 966) and South West India (private communication from Dr R. P. Devadas). I found in New Guinea that children and adults ate it readily. These regions are predominantly vegetarian or are accustomed to the use of powdered dried leaves. No attempt has, as yet, been made to win acceptance through the use of prestige but, as a prolude to this, we have devised a few (Morrison \& Pirie, I960; Byers, Green, \& Pirie, I 965) forms of presentation that may serve to interest others, with better qualifications, in more intensive work.

The last of the questions posed in the first paragraph necessitates a set of comparisons. They are notoriously odious and no form of advocacy for a novelty is as odious as the attempt to denigrate other novelties. But if comparisons are being made, the same criteria should be used throughout. All novelties are unfamiliar, many lack texture, the production technique for most has not been fully worked out, amino acid supplementation is equally applicable to any protein that would benefit from it, there are no observed production costs, and so on. I have heard all these general points raised in attempted specific denigration.

Though no costs are known some guesses can be made by analogy with the observed costs of similar processes. Empirics are likely to make these guesses more reliably than economists because economists seem unable to realize that they work in what should be an experimental science. Grass-drying is the nearest analogue to leaf protein production: the same type of crop would be used and the labour, housing and running expenses would be about the same. A firm can stay solvent while selling 'dried grass' containing $18 \%$ of protein for $£ 27$ a ton, i.e. 3 s. per $\mathrm{kg}$ of protein. If half the protein were being extracted, it would therefore cost $6 \mathrm{~s}$. $/ \mathrm{kg}$ if no allowance were made for the value of the residue as a fodder, or for the soluble leaf constituents as substrates for microbial growth. These by-products are however valuable, so my guess at the cost in Britain is $3-5 \mathrm{~s} . / \mathrm{kg}$ when a crop is grown solely as a source of leaf protein and less when by-product leaves are used. The cost of the protein in soya or skim milk (for as long as demand does not exceed the amount that is the by-product of making oil and butter) is similar.

The world's present need for protein, even on the niggardly allowance advocated by FAO, is so large that no single novel source could meet it for at least a decade. By then the population is likely to have increased still further. All the sources of protein discussed at this meeting are likely to be needed and research on all of them should be intensified. 'To say that any particular line has 'low priority' is tantamount to saying that research on it should be discontinued. 
Table 2. The ways in which some novel protein sources differ

Novel protein source

Fish: fresh, and protein made from mixed marine fauna

Leaves: for direct consumption or as sources of extracted protein

Oilseed residues

Wild animals

Yeasts and other microorganisms
Especial merits

Familiarity in principle though the 'fish' used and the endproduct may be novel

Most productive use of arable land in the wet tropics. Little need for transport

The source material already exists and production could be expanded

By browsing as well as grazing they make fuller use of land than domestic animals and are more resistant to many diseases

Use made of underused agricultural by-products and fossil fuels
Main limitation

Ultimate probable yield $<5 \%$ of total requirement. General consumption depends on efficient transport

The colour is unfamiliar

None, in suitable climates

Collection difficult and hygiene uncertain. Ultimate probable yield $<5 \%$ of total requirements

Sophisticated technique needed; this limits the number of contres of production

Table 2 attempts an assessment of the salient merits and demerits of various novel protein sources. The conclusion that $I$ reach is that the oilseeds are preeminent in regions where they grow well, and fish are pre-eminent on coasts adjacent to underexploited oceans. The point I have tried to bring out is that there is no one 'best' source. For people living beside an underexploited ocean, it would be fish; for those sparsely distributed on land that is not potentially arable, it would be game; in a tropical rain forest, leaves; in arable savannah, soya; and where there is abundant molasses, yeast. But however attractive the local 'best' source may seem in theory, it should never be allowed to dominate the scene so that people become heavily dependent on a single protein source. Most of us prefer a mixed diet and we are prudent to do so.

\section{REFERENCES}

Akinrele, I. A. (1963). $7 l W$. Afr. Sci. Ass. 8, 74 .

Buchanan, R. A. (r969a). F. Sci. Fd Agric. (In the Press.)

Buchanan, R. A. (1969b). F. Nutr. (In the Press.)

Byers, M. (1967a). F. Sci. Fd Agric, 18, 28.

Byers, M. (1967b). F. Sci. Fd Agric. 18, 33 .

Byers, M., Gteen, S. H. \& Pirie, N. W. (1965). Nutrition, Lond. 19, 63.

Chibnall, A. C., Rees, M. W. \& Lugg, J. W. H. (1963). F. Sci. Fd Agric. r4, 234.

Davys, M. N. G. \& Pirie, N. W. (1960). Engineering, Lond. 190, 274.

Davys, M. N. G. \& Pirie, N. W. (1965). 7. agric. Engng Res. 10, I42.

Davys, M. N. G. \& Pirie, N. W. (1969). Biotechnol. Bioengng. (In the Press.)

Davys, M. N. G., Pirie, N. W. \& Street, G. (r969). Biotechnol. Bioengng. (In the Press.)

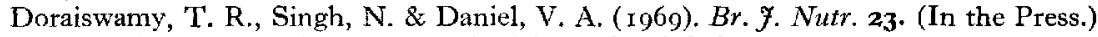

Duckworth, J. \& Woodham, A. A. (1961). F. Sci. Fd Agric. 12, 5.

Duckworth, J., IJepburn, W. R. \& Woodham, A. A. (1961). F. Sci. Fd Agric. 12, I6.

FAO (1965). F.A.O. Nutr. Mtg Rep. Ser. no. 37 .

Gerloff, E. D., Lima, I. H. \& Stahmann, M. A. (1965). F. agric. Fd Chem, 13, 139.

Henry, K. M. \& Ford, J. E. (1965). F. Sci. Fd Agric. 16, 425. 
Lima, I. H., Richardson, T. \& Stahmann, M. A. (1965). F. agric. Fd Chem. 13, 143.

Morrison, J. E. \& Piric, N. W. (1960). Nutrition, Lond. 14, 7.

Morrison, J. E. \& Pirie, N. W. (I961). F. Sci. Fd Agric. 12, 1.

Oke, O. L.. (1966). Nutrition, Land. 20, 18.

Pirie, N. W. (1966). Science, N.Y. 152, I701.

Pirie, N. W. (1968). International Symposium on Protein Foods and Concentrates. Mysore, I967.

Pleshkov, B. P. \& Fowden, L. (1959). Nature, Lond. 183, I 445.

Subba Rao, M. S., Singh, N. \& Prasannappa, G. (1967). F. Sci. Fd Agric. 18, 295.

United Nations (1968). International Action to avert the impending Protein Crisis. New York.

Waterlow, J. C. (1962). Br. Y. Nutr. 16, 531 .

Woodham, A. A. (1964). Outl. Agric. 4, I9o.

Woodham, A. A. (1965). Proc. Nutr. Soc. 24, xxiv.

\section{The production and evaluation of protein derived from organisms grown on hydrocarbon residues}

\section{By C. A. Shacklady, The British Petroleum Company Itd, Britannic House, Moor Lane, London, EC2}

'This paper can give no more than a summary of the subject indicated in the title partly because of the range covered and partly because the work is still in progress. It is hoped to publish details of the work, as it is completed, in the appropriate journals.

The organisms with which we are now concerned are yeasts produced by fermentation on either pure n-paraffins or heavy gas oil. Because of the absence of oxygen in these substrates, it is necessary to supply this as well as a nitrogen source-usually ammonia-and an aqueous solution of the minerals required for yeast growth. Thus the mixture is one of two immiscible liquids, a gas and a solid--the yeast--which must be kept in intimate contact under carefully controlled conditions for successful fermentation.

The process is continuous, which implies that harvesting and purification are also continuous. Essentially the main difference between the two processes, i.e. nparaffin and gas oil, is the need for a more complex purification stage in the case of the latter since only about $10 \%$ of the gas oil components are utilized in the actual production of the yeast. Our present intention is to operate the n-paraffin process at Grangemouth in Scotland and the gas oil process at Lavera in the South of France.

By the conventional $\mathrm{N} \times 6.25$ calculation, the protein content of $\mathrm{n}$-paraffin grown yeast (BP protein concentrate) is $63-65 \%$ and that from gas oil $68-70 \%$. But because of the different post-fermentation treatments the former contains approximately $9 \%$ of lipids, the latter about I $5 \%$. As might be expected, the amino acid composition of the protein is very similar in both cases and is shown in Table I along with that of fish meal and extracted soya-bean meal for comparison.

From this it would seem that the first limiting amino acid would be methionine and this indeed is borne out by determination of net protein utilization (NPU) and biological value (Bv). 